\title{
Analysis on Influence of Environmental Factors to the Heat Loss of Petrochemical Heating Furnace Wall
}

\author{
Fenghong $\operatorname{Pan}^{1, a *}$ and Jianjun Lan ${ }^{2, b}$ \\ ${ }^{1}$ School of Mechanical Engineering, Jilin Institute of Chemical Technology, Jilin, China \\ ${ }^{2}$ School of Automation Engineering, Northeast Dianli University, Jilin, China \\ a7612254@qq.com, ${ }^{b} 16703967 @ q q . c o m$
}

Keywords: Heating furnace; Wall of heating furnace; Heat loss; Infrared thermography

\begin{abstract}
As some workers in petrochemical enterprise usually take the outside wall temperature as a standard to determine the thermal insulation effects of the equipments, this paper discussed the influence of environment factors, as the temperature and wind speed to the heat loss of petrochemical heating furnace wall. Infrared thermo graphic technique was used to track and monitor the radiation section wall temperature of a delayed coking furnace. The result shows that environmental factors have drastic effects on the outside wall temperature, but less on the furnace wall heat loss. When evaluating the heat resistant property of a furnace can not only by its outside wall temperature, but by the actual calculating heat loss.
\end{abstract}

\section{Introduction}

Heat loss of the wall is a very important one of the petrochemical heating furnace's heat loss. To reduce heat loss the equipments are usually protected by insulation. The heat preservation effect affects not only the economic benefit of the enterprises but also normal operation of the equipment. Heat loss of the equipment must be diagnosed and estimated scientifically, the heat preservation reconstruction can be efficient. But some workers in petrochemical enterprise take the outside wall temperature as a standard to determine the thermal insulation effects of the equipments [1-3]. When determining the heat loss of heating furnace wall, the influence of environmental factors is usually neglected, and judging the thermal insulation property by the measurement result on one day of the year $[4,5]$. This paper explains the influence of environmental factors (the atmospheric temperature and wind speed) to the heat loss of the petrochemical heating furnace's wall in theory and reality.

\section{Heat Loss Calculation Method of the Heating Furnace's Wall}

The material is heated by the high temperature gas which is produced by the fuel burning in the hearth of petrochemical heating furnace. The heat transfer process should be described as follows: Heat firstly transferred from the high temperature gas to the inside wall by convection and radiation, second to the outer surface of heating furnace by conduction, and then to the atmospheric environment by convection and radiation, which will become a complete heat transfer process. In stable conditions, the heat loss of a plane wall should be calculated as the following formula:

$$
q=\frac{t_{i}-t_{f}}{\sum \frac{\delta_{i}}{\lambda_{i}}+\frac{1}{h_{0}}}
$$

Hereinto, $q$ is the heat loss of heating furnace wall $\left(W / \mathrm{m}^{2}\right) ; t_{i}$ is the temperature of inside wall $\left({ }^{\circ} \mathrm{C}\right) ; t_{f}$ is the environmental temperature $\left({ }^{\circ} \mathrm{C}\right) ; \delta_{i}$ is the thickness of each insulating layer of the wall $(\mathrm{m}) ; \lambda_{i}$ is the thermal conductivity of each insulating layer $(W /(m \cdot K))$; and $h_{o}$ is the surface coefficient of heat transfer between the outside wall and environment $\left(W /\left(\mathrm{m}^{2} \cdot K\right)\right)$ 


\section{Influence of Environment Factors to the Heat Loss of Heating Furnace Wall}

Heating furnaces in petrochemical industry are generally open arranged, and the outside wall contact with external environment directly. So, heat loss of the wall and the temperature of outside wall must be affected by the environment, the atmospheric temperature and wind speed effects $[6,7]$.

Influence of Environmental Temperature to the Heating Furnace Wall Heat Loss. Eq.1 shows that the temperature difference between the furnace inside wall and environment is the force of the furnace wall heat loss, the lower of environmental temperature $t_{f}$, the higher of the temperature difference force, and the bigger heat loss of the furnace wall.

Take the radiation section wall of a delayed coking furnace for example, the design parameters are described as following: the furnace inside wall temperature is $1100^{\circ} \mathrm{C}$ : from inside to outside, the furnace wall is comprised of refractory fiber block with thickness of $\delta_{1}=160 \mathrm{~mm}$, lightweight castable refractory with thickness of $\delta_{2}=140 \mathrm{~mm}$, and the Q235 steel with thickness of $\delta_{3}=6 \mathrm{~mm}$. The changing relationship of heat loss and the outside wall temperature of this section with environmental temperature are shown in Table 1.

As table 1 shows that with the environmental temperature changing from $-20^{\circ} \mathrm{C}$ to $30^{\circ} \mathrm{C}$, the furnace outside wall temperature increases of 142.3 percent, at the same time, the heat loss increases of only 4.5 percent. The result shows that the environmental temperature had drastic effect on the furnace outside wall temperature, but had little influence on the heat loss.

Table 1 The influence of environmental temperature

\begin{tabular}{ccccccc}
\hline temperature $\left[{ }^{\circ} \mathrm{C}\right]$ & -20 & -10 & 0 & 10 & 20 & 30 \\
\hline outside wall temperature $\left[{ }^{\circ} \mathrm{C}\right]$ & 33.8 & 43.4 & 53.1 & 62.7 & 72.3 & 81.9 \\
furnace wall heat loss $\left[\mathrm{W} / \mathrm{m}^{2}\right]$ & 728.4 & 721.9 & 715.3 & 708.7 & 702.2 & 695.6 \\
\hline
\end{tabular}

Influence of Wind Speed to the Heating Furnace Wall Heat Loss. When the air flows through the heating furnace outside surface with a certain speed, the grater of the wind speed, the more disturbance of the air to boundary layer, and accordingly the surface coefficient of heat transfer between the outside wall and environment will increase, and it will lead to more heat loss.

Also, take the radiation section wall of the delayed coking furnace for example, the changing relationship of heat loss and the wind speed is shown in Table 2 when the environmental temperature keeping with $20^{\circ} \mathrm{C}$.

Table 2 The influence of wind speed

\begin{tabular}{ccccccc}
\hline wind speed $[\mathrm{m} / \mathrm{s}]$ & 0 & 4 & 8 & 12 & 16 & 20 \\
\hline outside wall temperature $\left[{ }^{\circ} \mathrm{C}\right]$ & 72.3 & 48.0 & 43.0 & 40.2 & 38.3 & 36.9 \\
furnace wall heat loss $\left[\mathrm{W} / \mathrm{m}^{2}\right]$ & 702.2 & 718.7 & 722.2 & 724.1 & 725.4 & 726.3 \\
\hline
\end{tabular}

Table 2 shows that the wind speed also affects the furnace outside wall temperature more severely than the heat loss. The outside surface temperature and the furnace wall heat loss had larger rangeability when the wind speed changing from $0 \mathrm{~m} / \mathrm{s}$ to $4 \mathrm{~m} / \mathrm{s}$ than the rest stage. That is because that heat transfers by natural convection when the wind speed is $0 \mathrm{~m} / \mathrm{s}$, and by forced convection when it is windy, the former is generally much more intensive.

Table 3 shows the changing of the outside wall temperature and the heat loss with the environmental factors when the environmental temperature and wing speed has synchronous changes. 
Table 3 The influence of environmental temperature and wing speed together

\begin{tabular}{cccc}
\hline Temperature $\left[{ }^{\circ} \mathrm{C}\right]$ & Wind speed $[\mathrm{m} / \mathrm{s}]$ & $\begin{array}{c}\text { Outside wall } \\
\text { Temperature }\left[{ }^{\circ} \mathrm{C}\right]\end{array}$ & $\begin{array}{c}\text { Furnace wall } \\
\text { heat loss }\left[\mathrm{W} / \mathrm{m}^{2}\right]\end{array}$ \\
\hline-20 & 5 & 7.4 & 746.5 \\
-10 & 4 & 18.8 & 738.9 \\
0 & 3 & 30.8 & 730.5 \\
10 & 2 & 43.5 & 721.8 \\
20 & 1 & 58.2 & 711.8 \\
30 & 0 & 81.9 & 695.6 \\
\hline
\end{tabular}

\section{Application Example}

Heat flux of every process through the furnace wall is the same in stable condition; it can be described as the following equation:

$$
q=\frac{t_{i}-t_{f}}{\sum \frac{\delta_{i}}{\lambda_{i}}+\frac{1}{h_{o}}}=\frac{t_{o}-t_{f}}{\frac{1}{h_{o}}}
$$

Hereinto, $t_{o}$ is the furnace outside surface temperature, ${ }^{\circ} \mathrm{C}$.

So, the heating furnace wall heat loss can be figured out by measuring the furnace outside wall temperature. In this paper, the thermal infrared imager was used to get the foregoing delayed coking furnace radiation section wall surface temperature, Fig. 1 and Fig. 2 were respectively the infrared thermograms of the furnace wall in June and November. The infrared thermograph has the advantages of quick speed, high sensitivity, wide measuring range, and non-contact, etc, with which the temperature distribution of equipments surface can be got more exactly [8-10]. The furnace outside wall temperature and heat loss in June and November are obtained as shown in Table 4.

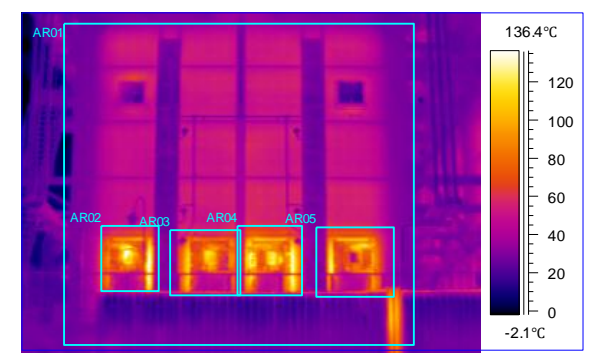

Figure 1. Infrared thermogram of June

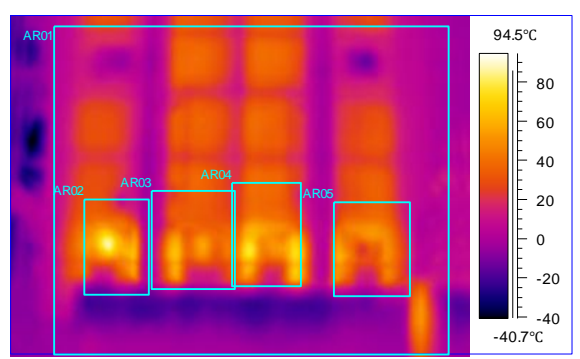

Figure 2. Infrared thermogram of November 
Table 4 Computational result of the application example

\begin{tabular}{|c|c|c|c|c|}
\hline \multirow{2}{*}{ Time } & \multicolumn{2}{|c|}{ temperature $\left[{ }^{\circ} \mathrm{C}\right]$} & \multirow{2}{*}{$\begin{array}{c}\text { Wind Speed } \\
{[\mathrm{m} / \mathrm{s}]}\end{array}$} & \multirow{2}{*}{$\begin{array}{c}\text { Heat loss } \\
{\left[\mathrm{W} / \mathrm{m}^{2}\right]}\end{array}$} \\
\hline & Environmental & outside wall & & \\
\hline Jun & 16.2 & 44 & 3.8 & 702.7 \\
\hline Nov & -10.1 & 19 & 4.0 & 745.8 \\
\hline
\end{tabular}

The calculation confirmed the preceding analysis of environment factors affecting the heat loss of petrochemical heating furnace wall. So, the actual calculating heat loss should be adopted as standard instead of the furnace outside surface temperature when measuring the heat loss and estimating the heat preservation of the thermal equipments.

\section{Conclusions}

Environmental factors have drastic effects on the outside surface temperature of petrochemical heating furnace wall, but less on the furnace wall heat loss. So, the field test conditions prescribed in literature [1] and [2] can be used to testing the heat loss and estimating the heat preservation of heating furnaces in central and southern regions in China.

The influence of environmental factors should be appropriate considered when designing a furnace and testing the heat loss in the northern regions with large fluctuations in wind speed and temperature.

\section{References}

[1] L. Gu: Industrial Furnace, Vol. 29 (2007) No.5, p.24. (In Chinese)

[2] J.L. Zhou, X.Q. Cheng and Y. Hu: Infrared Technology, Vol. 30 (2008) No.10, p. 595. (In Chinese)

[3] T.S. Yang, Q. Ouyang and X. H. Ni: Henan Metallurgy, Vol. 12 (2004) No.2, p. 19. (In Chinese)

[4] SY/T6421-1999, Determination of equipments and pipes heat loss[S]. Beijing: national petroleum and chemical industry bureau, 2000, p. 5. (In Chinese)

[5] Q/SY0050-2002, Energy conservation testing method of petrochemical process heating furnace $[S]$. China national petroleum corporation, 2002, p. 1. (In Chinese)

[6] S.M. Yang and W.Q.Tao:Heat Transfer (Higher Education Press, China 2006), p. 197. (In Chinese)

[7] G.L. Xu, X.M. Wang, T.H. Wu and W.H. Chen: Engineering Heat Transfer (China Electric Power Press, China 2010), p. 66. (In Chinese)

[8] G.X. Jin, D. Xu and F.H. Pan: Infrared Technology, Vol. 31 (2009) No.11, p. 668. (In Chinese)

[9] V. P. Vavilov, V. G. Demin and V. V. Shiryaev: Russian Journal of Nondestructive Testing, (2003) No.9, p. 657.

[10] H. Sun: Industrial Furnace, Vol. 33 (2011) No.6, p. 28. (In Chinese). 